\title{
EFFECT OF INITIAL BODY WEIGHT AND STOCKING DENSITY ON GROWTH PERFORMANCE OF FRESH- WATER PRAWN (M. rosenbergii) POST-LARVAE AND JUVENILES
}

\author{
M.S. El-Sherif, H.M. Khouraiba and Mervat A.M. Ali \\ Animal Production and Fish Resources Department, Faculty of Agriculture, Suez \\ Canal University, Ismailia, Egypt
}

\section{SUMMARY}

Freshwater prawn-postlarvae, M. rosenbergii averaging $0.04 \pm 0.001 \mathrm{~g}$ in weight [Experiment 1] were reared for 90day at four stocking densities (200, 400, 800 and 1200 prawn $\left./ \mathrm{m}^{2}\right)$ using 12 circular fiberglass tanks $\left(0.36 \mathrm{~m}^{2}\right.$ and $0.6 \mathrm{~m}$ water depth). Prawns were fed a manufactured diet containing $35 \%$ crude protein. Different growth measurements of prawn were recorded at 15 days intervals. The results showed that growth performance was significantly $(P \leq 0.05)$ decreased with increasing the stocking density. Survival rate was inversely related to stocking densities, since there were significant differences among the four densities. The food conversion ratio "FCR" increased with increasing stocking density, the differences were significant among the four densities.

In the second experiment freshwater prawn-juveniles, $M$. rosenbergii averaging $0.30 \pm 0.02 \mathrm{~g}$ in weight were cultured for 90 days, with different stocking densities (50, 100, 150 and 200 prawn $/ \mathrm{m}^{2}$ ) using the same method as in first experiment. The results showed that growth performance was significantly $(P \leq 0.05)$ decreased with increasing the stocking density. Survival rate was inversely related to stocking density, since there were significant differences among the four densities, while the difference between stocking density of 50 and 100 prawn $/ \mathrm{m}^{2}$-was not significant. The food conversion ratio "FCR" increased with increasing the stocking densities, since the fourth density (200 prawn $\left./ \mathrm{m}^{2}\right)$ was significantly higher than that achieved in the first one (50 prawn $/ \mathrm{m}^{2}$ ). Increasing stocking density resulted in increasing carcass protein and ash content, while carcass fat and dry matter content decreased but differences were not significant.

Therefore, it could be concluded that monoculture of freshwater prawn juveniles (average weight $0.3 \mathrm{~g}$ \& stocking density $50 \mathrm{prawn} / \mathrm{m}^{2}$ ) and postlarvae (average weight $0.04 \mathrm{~g} \&$ stocking density $200 \mathrm{prawn} / \mathrm{m}^{2}$ ) were more suitable to carry out for optimum growth performance and survival rate.

Keywords: Freshwater prawn (M. rosenbergii), Post-larvae-juveniles, stocking density, growth performance

\section{INTRODUCTION}

Production of the freshwater prawn (Macrobrachium rosenbergii) has increased substantially in recent years. These increases are partially based on several positive production attributes which include resistance to the diseases which have severally impacted penaeid production (Wang et al., 1998), the potential of producing large

Issued by The Egyptian Society of Animal Production 
average sizes (New, $2000 \mathrm{a} \& \mathrm{~b}$ ), and the recognition that prawn culture may be more environmentally sustainable than intensive penaeid shrimp production (Tidwell and D'Abramo, 2000). Culture systems of freshwater prawn, however, began to be developed only after the life cycle of Macrobrachiun rosenbergii was closed in a Malaysian laboratory (Ling, 1977). This stimulated widespread interest in the culture of this species and other palaemonidss. Thus, freshwater prawn farming continued to expand elsewhere. At the present time, the annual world production of $M$. rosenbergii reached 27000 metric tones, the majority of which are from South-east Asian countries (Tidwell et al., 2004). It is desirable to determine an optimum stocking rate which allows high growth rates of all individuals stocked together with high survival. The usual densities tested in grow-out ponds range from 1 to 20 prawns stocked $/ \mathrm{m}^{2}$ (Ra'anan, 1982). In Egypt, the culture of freshwater prawns (M. rosenbergii) has great economic interest for the following reasons: wide brackish surfaces are available, the climatic situation is very favorable and the market prices are high. The climate permits outdoor cultivation of freshwater prawns only during the warmer nine months of the year (El-Gayar et al., 1994). The aims of this study were to investigate the effect of different sizes and stocking densities on rearing of freshwater prawn (M. rosenbergii) post-larvae and juveniles in tanks.

\section{MATERIALS AND METHODS}

This study was carried out at Fish Research Center (F.R.C.), Suez Canal University, Ismailia, Egypt, in order to determine the effect of sizes and stocking densities of freshwater prawn (M.rosenbergii) on growth performance, survival rate, and carcass composition of prawn.

Experimental prawn:

Freshwater prawn (Macrobrachium rosenbergii) post-larvae and juveniles used in this study were obtained from the Maryut Fish Farming Company, Alexandria in aerated tanks. Freshwater prawn were graded, homogeneous sizes were selected and kept in circular tank for each. They were fed for fifteen days on the same diet which used in this study, to adapt them for the experimental conditions. Unhealthy prawns were removed from the tanks and replaced with others healthy.

\section{Experimental tanks:}

Twenty four fiberglass circular tanks $\left(0.36 \mathrm{~m}^{2}\right.$ each, mean depth $\left.0.6 \mathrm{~m}\right)$ were used for rearing the freshwater prawn in both experiments. Water in tanks was obtained from a well and aerated by a constant supply of air blower. PVC pipes have been used in tanks to provide shelters for prawns and reduce aggressive interaction (Lee and Wickins, 1992). Faeces were siphoned together with $20 \%$ of the water volume from each tank and replaced with fresh water daily, before morning feeding. Experimental design:

\section{Experiment 1:}

This experiment was devoted to study the effect of stocking densities on growth performance, and survival rate of prawn-postlarvae. Twelve circular tanks were used and stocked with prawn-postlarvae averaging $0.04 \pm 0.001 \mathrm{~g}$ in weight (Willis and Berrigan, 1979). Prawns were stocked in tanks at four different stocking densities i.e. 200, 400, 800, 1200 per square mater (Chen, 1990). Each stocking density had three replicates. 


\section{Experiment 2:}

Prawn juveniles were stocked in the twelve circular tanks at four different stocking densities i.e. 50, 100, 150, 200 prawns $/ \mathrm{m}^{2}$ with three replicates for each density. At the stocking time, average weight of prawn juveniles were $0.3 \pm 0.02 \mathrm{~g}$ in weight (Tidwell et al., 2005). The experimental period lasted 90 days.

During rearing period in both experiments, the physical-chemical analysis of water (temperature, $\mathrm{pH}$, dissolved oxygen, total hardness, salinity), growth performance and survival rate of prawns were determined every 15 days intervals.

\section{Experimental diet:}

The diet used in feeding the experimental prawn was obtained from Sinai Shrimps 21 Company, Port Said its compassion was according to (NRC, 1983). The diet was grounded to very small size of less than $15 \mathrm{~mm}$ mesh and stored in a refrigerator $\left(4^{\circ} \mathrm{C}\right)$ during the experimental duration to avoid the nutrients deterioration. The ingredients composition and proximate analysis of this diet are provided in Table (1).

Table 1. Ingredients composition and proximate analysis of the diet fed to prawns in this study

\begin{tabular}{lc}
\hline Ingredients & $\%$ \\
\hline Fish meal & 15.0 \\
Soybean meal & 36.0 \\
Crab meal & 10.0 \\
Corn gluten meal & 20.0 \\
Wheat bran & 12.0 \\
Fish oil & 2.0 \\
Pellet binder * & 2.0 \\
Vitamin mix ** & 0.5 \\
Trace mineral mix *** & 0.5 \\
Dicalcium phosphate & 1.25 \\
Choline chloride & 0.05 \\
Ascorbic acid & 0.70 \\
\hline - Chemical composition of the diet (\% as fed): & $\%$ \\
Moisture & 12.9 \\
Ash & 10.8 \\
Crude protein & 35.0 \\
Crude fat & 05.0 \\
Crude fiber & 03.0 \\
Nitrogen-free extract & 33.3 \\
\hline * Pellet binder was hemicellulose. & \\
$* *$ Vitamin mix contains: thiamin,1.01\%; riboflavin, 1.32\%; pyridoxine, $0.9 \% ;$ nicotinic acid, $8.82 \% ;$ folic \\
acid, 0.22\%; vitamin B12, 0.001\%; pantothenic acid, 3.53\%; menadion, $0.2 \%$ ascorbic acid, 33.07\%; \\
vitamin A, 4,409,200(IU)/kg; vitamin D3 ,2,204,600(IU)/kg; vitamin E, 66,138(IU)/kg; ethoxyquin, \\
0.66\%. \\
*** Trace mineral mix contains: Mn, 10.0\%; Zn, 10.8\%; Fe, 7.0\%; Cu, 0.7\%; I, 0.24\%; Co, $0.10 \%$; Ca \\
(carrier).
\end{tabular}

\section{Feeding regime:}

The daily feeding rate for the first week was $20 \%$ of the total stocking biomass and thereafter was adjusted at the beginning of each of the next two weeks. Every 
two weeks thereafter, tank samples provided information for the adjustment of feeding quantity based on actual prawn biomass in each tank. The freshwater prawns were fed the experimental diet twice a day at 9.00 am and 5.00 p.m. A feeding rate assigned to a particular range of wet weights (Table 2) according to D' Abramo et al., (1989). The experimental diet was offered by hand spreading.

Table 2. Weight dependent feeding rates used to determine biweekly feeding schedules for grow out tanks

\begin{tabular}{cc}
\hline Weight $(\mathbf{g})$ & Daily fed as percentage of body weight \\
\hline $0-1$ & 20 \\
$1-2$ & 15 \\
$2-5$ & 12 \\
$5-10$ & 9 \\
$10-15$ & 8 \\
$15-20$ & 7 \\
$20-25$ & 6 \\
$25-30$ & 5 \\
$30 \sim$ & 3 \\
\hline
\end{tabular}

\section{Physical and chemical analysis of water:}

Water temperature was measured using oxygen- temperature meter (YSI model L57). Water temperature of the experimental tankes was monitored daily throughout the experimental period (Marques et al., 2000) and the average was taken per 15 days. Water $\mathrm{pH}$ was measured using $\mathrm{pH}$ meter (model 56, NR $87 \mathrm{BB} 203$ ). The $\mathrm{pH}$ values of each tank was monitored daily in the late afternoon (D'Abramo et al., 1989). The average $\mathrm{pH}$ values of water was recorded every 15 days intervals throughout the experimental period. The dissolved oxygen in the water was measured by using oxygen- temperature meter (YSI model L 57). Concentration of dissolved oxygen $(\mathrm{mg} / \mathrm{L})$ of each tank was measured daily during the early morning and the average dissolved oxygen of water was recorded every 15 days intervals during the experimental period (D'Abramo et al., 1989). Salinity of water was determined using a refractometer, ATAGO. Total hardness of water throughout the experimental period was estimated using the method described by Brown et al. (1991).

Parameters tested:

Whole prawn carcass was analyzed for protein, fat, ash and moisture contents by standard AOAC (1990) methods. The following parameters were used to evaluate prawn growth performance in both experiments:

Mean Prawn Weight $=$ the average weight of prawn at $t$ days

Weight Gain $(\mathrm{WG})=\mathrm{W}_{1}-\mathrm{W}_{0}$

Average Daily Weight Gain $(\mathrm{ADG})=\left(\mathrm{W}_{1}-\mathrm{W}_{0}\right) / \mathrm{t}$

Percentage Weight Gain $(\%)=\left(\mathrm{W}_{1}-\mathrm{W}_{0}\right) \mathrm{X} 100 / \mathrm{W}_{0}$

Specific Growth Rate (\% day) SGR $=\left(\mathrm{Ln} \mathrm{W}_{1}-\mathrm{Ln} \mathrm{W}_{0}\right) \mathrm{X} 100 / \mathrm{t}$

Food Conversion Ratio $(\mathrm{FCR})=$ feed fed $/\left(\mathrm{W}_{1}-\mathrm{W}_{0}\right)($ De- Silva and Anderson, 1995) .

Survival rate $(\%)=\mathrm{N}_{\mathrm{i}} \mathrm{X} 100 / \mathrm{N}_{0}$ (Harrell et al., 1990).

Where:

$\mathrm{W}_{1}=$ Final wet weight $(\mathrm{g})$
$\mathrm{W}_{0}=$ Initial wet weight $(\mathrm{g})$ 
$\mathrm{t}=$ Time interval in days

$\mathrm{N}_{\mathrm{i}}=$ Number of prawn at the end

$\mathrm{N}_{0}=$ Number of prawn initial stocked

Statistical analysis:

The data obtained in this study were analyzed by one-way ANOVA procedure of Statistical Analysis System (SAS, 1988). Means were compared by Duncan's new multiple range test (Zar, 1996).

\section{RESULTS AND DISCUSSION}

\section{Environmental conditions:}

The recorded values in Table (3) showed suitable environmental conditions for rearing of freshwater prawn (M. rosenbergii) during the experimental period. The water temperature ranged from $26.5^{\circ} \mathrm{C}$ to $27.6^{\circ} \mathrm{C}$. These values were within the acceptable range of temperature recorded for $M$. rosenbergii (New and Singholka, 1985). These results are in agreement with those obtained by Sadek and Moreau (1996). They noticed that optimal water temperatures for optimum growth and survival of $M$. rosenbergii are $26-31^{\circ} \mathrm{C}$. Also, Marques et al. (2000) found that, the optimal temperature for $M$. rosenbergii is 23.5 to $27^{\circ} \mathrm{C}$. Changes in $\mathrm{pH}$ values of water during the experimental period were illustrated in Table (3). It is clear that the minimum $\mathrm{pH}$ value was 7.5 and the maximum $\mathrm{pH}$ was 8.2. This range was in the optimum range of $\mathrm{pH}$ recorded for Macrobrachium rosenbergii (Sadek and El-Gayar, 1993). Similar results were obtained by Mei Chen and Chu-Chen (2003). They indicated that, optimal $\mathrm{pH}$ values for optimum growth and survival rate of $M$. rosenbergii are 7.4-8.2. Also, Tidwell et al. (2004) noted that, $\mathrm{pH}$ values for $M$. rosenbergii varied from 8.0 to 9.6 (mean of $8.9 \pm 0.3$ ). Throughout the experimental period, the dissolved oxygen was measured and Table (3) illustrate the changes in the mean values of dissolved oxygen concentrations. It is clear from the data that the minimum and maximum value of the dissolved oxygen were 5.8 and $6.5 \mathrm{mg} / \mathrm{L}$., respectively. This range was suitable for $M$. rosenbergii feeding and growth as reported by Tidwell et al. (2004).

As shown in Table (3) the minimum and maximum value of the salinity, during the rearing period, were 0.12 and $0.23 \%$, respectively. It is clear from the data that the salinity was suitable for the growth of M. rosenbergii. Sadek and Moreau (1996) found optimal growth and survival rate for $M$. rosenbergii in either freshwater or water of low salinity (2\%o). On the other hand, Sadek and El-Gayar (1993) reported that, optimal salinities for growth and survival to metamorphosis for $M$. rosenbergii have been generally reported as 7.2 - 15\%. From the data recorded, it can be seen that the lowest value of total hardness was $(65.3 \mathrm{mg} / \mathrm{L}$.), while the highest value was, $74.2 \mathrm{mg} / \mathrm{L}$. The water having this hardness is suitable for M. rosenbergii. Similar results were obtained by New and Singholka (1985). They indicated that, optimum water hardness levels for optimal growth and survival for $M$. rosenbergii appear to lie between 65 and 200mg/L. Also, Brown et al. (1991) found that, at hardness levels between 30 and $75 \mathrm{mg} / \mathrm{L} \mathrm{CaCO}_{3}$, survival was good, ranging from 67 to $100 \%$ (mean 92.5\%). 
Table 3. Mean values of physical and chemical characteristics of water during the whole experimental period (90 day) for both experiments

\begin{tabular}{cccccc}
\hline $\begin{array}{c}\text { Period of } \\
\text { rearing } \\
(\text { day })\end{array}$ & $\begin{array}{c}\text { Water } \\
\text { temperature } \\
\left({ }^{\circ} \mathrm{C}\right)\end{array}$ & $\mathrm{pH}$ & $\begin{array}{c}\text { Dissolved } \\
\text { oxygen } \\
(\mathrm{mg} / \mathrm{L})\end{array}$ & $\begin{array}{c}\text { Salinity } \\
(\mathrm{ppt})\end{array}$ & $\begin{array}{c}\text { Total hardness } \\
(\mathrm{mg} / \mathrm{L})\end{array}$ \\
\hline 15 & 26.5 & 7.5 & 6.5 & 0.12 & 65.5 \\
30 & 26.7 & 7.8 & 6.3 & 0.12 & 65.3 \\
45 & 27.5 & 8.1 & 5.9 & 0.22 & 74.0 \\
60 & 27.6 & 8.2 & 5.8 & 0.23 & 74.2 \\
75 & 27.3 & 8.0 & 6.0 & 0.22 & 73.5 \\
90 & 26.8 & 7.9 & 6.2 & 0.13 & 68.1 \\
\hline
\end{tabular}

Experiment 1:

Mean individual weights:

Table (4) illustrates the mean individual weight of $M$. rosenbergii-postlarvae in tanks for 90 days at different stocking densities (i.e. 200, 400, 800 and 1200 prawn $/ \mathrm{m}^{2}$ ). It can be noticed from the data that mean initial weight of post-larvae at stocking was $0.04 \pm 0.001 \mathrm{~g}$ for all densities. At the end of the experimental period, the final average body weights (FBW) of $M$. rosenbergii-postlarvae were 1.302 , $1.220,0.634$ and $0.438 \mathrm{~g}$ for densities 200, 400, 800 and $1200 \mathrm{prawn} / \mathrm{m}^{2}$, respectively. It can be concluded that the maximum and the minimum sizes of $M$. rosenbergii-postlarvae were attained at lower and higher stocking rates, respectively (being 1.302 and $0.438 \mathrm{~g}$ ). The statistical analysis of mean results indicated that the mean individual weight of $M$. rosenbergii-postlarvae was not significantly $(\mathrm{P}>0.05)$ different between the stocking densities of 200 and 400 prawn $/ \mathrm{m}^{2}$, but the differences between densities of 200, 400, 800 and 1200 prawn $/ \mathrm{m}^{2}$ were significant $(\mathrm{P}<0.05)$. Such results coincide with those of Marques et al. (2000). They reported that prawn weight decreased when density increased.

Table 4. Effect of different stocking densities in the first experiment on mean individual weight (g) of Macrobrachium rosenbergii, post-larvae (Mean $\pm \mathrm{SE}$ )

\begin{tabular}{cllll}
\hline \multirow{2}{*}{ Period(day) } & \multicolumn{4}{c}{ Stocking rate $\left(\right.$ Prawn $\left./ \mathrm{m}^{2}\right)$} \\
\cline { 2 - 5 } & \multicolumn{1}{c}{200} & \multicolumn{1}{c}{400} & 800 & 1200 \\
\hline At-stocking & $0.04 \pm 0.001$ & $0.04 \pm 0.001$ & $0.04 \pm 0.001$ & $0.04 \pm 0.001$ \\
15 & $0.079 \pm 0.006^{\mathrm{a}}$ & $0.078 \pm 0.001^{\mathrm{a}}$ & $0.071 \pm 0.002^{\mathrm{a}}$ & $0.066 \pm 0.006^{\mathrm{a}}$ \\
30 & $0.152 \pm 0.001^{\mathrm{a}}$ & $0.148 \pm 0.006^{\mathrm{a}}$ & $0.119 \pm 0.001^{\mathrm{b}}$ & $0.105 \pm 0.002^{\mathrm{b}}$ \\
45 & $0.284 \pm 0.006^{\mathrm{a}}$ & $0.274 \pm 0.001^{\mathrm{a}}$ & $0.190 \pm 0.001^{\mathrm{b}}$ & $0.161 \pm 0.002^{\mathrm{b}}$ \\
60 & $0.497 \pm 0.001^{\mathrm{a}}$ & $0.479 \pm 0.006^{\mathrm{a}}$ & $0.293 \pm 0.006^{\mathrm{b}}$ & $0.235 \pm 0.006^{\mathrm{b}}$ \\
75 & $0.829 \pm 0.006^{\mathrm{a}}$ & $0.786 \pm 0.001^{\mathrm{a}}$ & $0.437 \pm 0.002^{\mathrm{b}}$ & $0.329 \pm 0.002^{\mathrm{c}}$ \\
90 & $1.302 \pm 0.002^{\mathrm{a}}$ & $1.220 \pm 0.002^{\mathrm{a}}$ & $0.634 \pm 0.002^{\mathrm{b}}$ & $0.438 \pm 0.006^{\mathrm{c}}$ \\
\hline Means with different superscripts within the same row are significantly different $(\mathrm{P}<0.05)$.
\end{tabular}

Mean weight gain:

Table (5) illustrates the mean weight gain at 15 days intervals for all treatments. This table indicated that weight gain at the end of the experimental period was 0.473 , $0.434,0.197$ and $0.109 \mathrm{~g} /$ prawn for the stocking densities 200, 400, 800 and 1200 prawn $/ \mathrm{m}^{2}$, respectively. It can be seen that the average weight gain per prawn in the experimental groups was decreased with increasing stocking densities. Similar results were obtained by Marques et al. (2000). Generally, significant $(\mathrm{P} \leq 0.05)$ differences 
were found among the stocking rates. But the difference was not significant between stocking rates 200 and 400 prawn $/ \mathrm{m}^{2}$.

Table 5. Effect of different stocking densities in the first experiment on mean weight gain (g/prawn) of Macrobrachium rosenbergii, post-larvae (Mean $\pm \mathrm{SE}$ )

\begin{tabular}{ccccc}
\hline \multirow{2}{*}{ Period(day) } & \multicolumn{4}{c}{ Stocking rate (Prawn / m $\mathbf{~}^{\mathrm{C}}$ ) } \\
\cline { 2 - 5 } & $\mathbf{2 0 0}$ & $\mathbf{4 0 0}$ & $\mathbf{8 0 0}$ & $\mathbf{1 2 0 0}$ \\
\hline 15 & $0.039 \pm 0.002^{\mathrm{a}}$ & $0.038 \pm 0.001^{\mathrm{a}}$ & $0.031 \pm 0.006^{\mathrm{b}}$ & $0.026 \pm 0.001^{\mathrm{c}}$ \\
30 & $0.073 \pm 0.001^{\mathrm{a}}$ & $0.070 \pm 0.001^{\mathrm{a}}$ & $0.048 \pm 0.001^{\mathrm{b}}$ & $0.039 \pm 0.002^{\mathrm{c}}$ \\
45 & $0.132 \pm 0.006^{\mathrm{a}}$ & $0.126 \pm 0.002^{\mathrm{a}}$ & $0.071 \pm 0.002^{\mathrm{b}}$ & $0.056 \pm 0.006^{\mathrm{c}}$ \\
60 & $0.213 \pm 0.001^{\mathrm{a}}$ & $0.205 \pm 0.002^{\mathrm{a}}$ & $0.103 \pm 0.006^{\mathrm{b}}$ & $0.074 \pm 0.002^{\mathrm{c}}$ \\
75 & $0.332 \pm 0.002^{\mathrm{a}}$ & $0.307 \pm 0.001^{\mathrm{a}}$ & $0.144 \pm 0.001^{\mathrm{b}}$ & $0.094 \pm 0.001^{\mathrm{c}}$ \\
90 & $0.473 \pm 0.001^{\mathrm{a}}$ & $0.434 \pm 0.001^{\mathrm{a}}$ & $0.197 \pm 0.001^{\mathrm{b}}$ & $0.109 \pm 0.002^{\mathrm{c}}$ \\
\hline
\end{tabular}

\section{The average daily weight gain (ADG):}

Table (6) illustrated the changes in the average daily weight gain of prawn reared in tanks under different stocking densities (i.e. 200, 400, 800 and 1200 prawn $/ \mathrm{m}^{2}$ ). It can be seen from the table that the average daily weight gains at the end of the experimental period were $0.032,0.029,0.013$ and $0.007 \mathrm{~g} /$ prawn for stocking densities 200, 400, 800 and 1200 prawn $/ \mathrm{m}^{2}$, respectively. The gain per prawn per day decreased as the stocking density increased. Since the maximum average gain per prawn per day was attained at the stocking density of $200 \mathrm{prawn} / \mathrm{m}^{2}$. It decreased by increasing the stocking density from 200 to 1200 prawn $/ \mathrm{m}^{2}$. Similar results were obtained by Sadek and Moreou (1996). The statistical analysis showed that there were significant differences among the average daily weight gains of the prawn at the different stocking densities. But the differences were not significant among stocking density 200,400 and 800 prawn $/ \mathrm{m}^{2}$ on one side and between 800 and 1200 prawn $/ \mathrm{m}^{2}$ on the other side.

Table 6. Effect of different stocking densities in the first experiment on average daily weight gain (ADG) (g/prawn) of Macrobrachium rosenbergii, post-larvae $($ Mean \pm SE)

\begin{tabular}{|c|c|c|c|c|}
\hline \multirow{2}{*}{ Period(day) } & \multicolumn{4}{|c|}{ Stocking rate $\left(\right.$ Prawn $\left./ \mathrm{m}^{2}\right)$} \\
\hline & 200 & 400 & 800 & 1200 \\
\hline 15 & $0.0026 \pm 0.001^{\mathrm{a}}$ & $0.0025 \pm 0.001^{\mathrm{a}}$ & $0.0020 \pm 0.006^{\mathrm{a}}$ & $0.0017 \pm 0.006^{\mathrm{a}}$ \\
\hline 30 & $0.0048 \pm 0.006^{\mathrm{a}}$ & $0.0045 \pm 0.006^{\mathrm{a}}$ & $0.0032 \pm 0.001^{\mathrm{a}}$ & $0.0026 \pm 0.001^{\mathrm{a}}$ \\
\hline 45 & $0.0090 \pm 0.001^{\mathrm{a}}$ & $0.0080 \pm 0.002^{\mathrm{ab}}$ & $0.0050 \pm 0.001^{\mathrm{ab}}$ & $0.0040 \pm 0.006^{\mathrm{b}}$ \\
\hline 60 & $0.014 \pm 0.002^{\mathrm{a}}$ & $0.013 \pm 0.001^{\mathrm{a}}$ & $0.007 \pm 0.001^{\mathrm{b}}$ & $0.005 \pm 0.001^{\mathrm{b}}$ \\
\hline 75 & $0.022 \pm 0.006^{\mathrm{a}}$ & $0.020 \pm 0.002^{\mathrm{a}}$ & $0.010 \pm 0.001^{\mathrm{a}}$ & $0.006 \pm 0.002^{\mathrm{a}}$ \\
\hline 90 & $0.032 \pm 0.002^{\mathrm{a}}$ & $0.029 \pm 0.006^{\mathrm{a}}$ & $0.013 \pm 0.001^{\mathrm{b}}$ & $0.007 \pm 0.006^{\mathrm{c}}$ \\
\hline
\end{tabular}

Means with different superscripts within the same row are significantly different $(\mathrm{P}<0.05)$.

Relative growth rate (RGR) :

Table (7) shows RGR of $M$. rosenbergii-post larvae for all treatments. The results indicated that the RGR of prawn for different stocking densities was initially high and then gradually declined. These results are in agreement with the finding of AlFarsi (1997), who found that RGR of Penaeus japonicus was decreased gradually with time. From data obtained, it could be noticed thate the RGR of M. rosenbergiipost larvae varied by varying the stocking density, since the RGR decreased as the 
stocking density increased (from 200 prawn $/ \mathrm{m}^{2}$ to 400,800 and $1200 \mathrm{prawn} / \mathrm{m}^{2}$ ). It can be seen that the RGR at the end of the experimental period were 57.1, 55.2, 45.1 and $33.1 \%$ for stocking densities $200,400,800$ and $1200 \mathrm{prawn} / \mathrm{m}^{2}$, respectively. The mean data, showed that there were significant differences between the RGR of the prawn at the different stocking densities. But the difference between stocking density 200 and 400 prawn $/ \mathrm{m}^{2}$ was non significant. This is in full agreement with that found by Marques et al. (2000).

Table 7. Effect of different stocking densities in the first experiment on mean relative growth rate (\% growth) of Macrobrachium rosenbergii, post-larvae $($ Mean \pm SE)

\begin{tabular}{ccccc}
\hline \multirow{2}{*}{ Period (day) } & \multicolumn{4}{c}{ Stocking rate (Prawn $\left./ \mathrm{m}^{2}\right)$} \\
\cline { 2 - 4 } & 200 & 400 & 800 & 1200 \\
\hline 15 & $97.5 \pm 0.12^{\mathrm{a}}$ & $95.0 \pm 0.17^{\mathrm{b}}$ & $77.5 \pm 0.06^{\mathrm{c}}$ & $65.0 \pm 0.17^{\mathrm{d}}$ \\
30 & $92.0 \pm 0.17^{\mathrm{a}}$ & $89.7 \pm 0.12^{\mathrm{b}}$ & $67.6 \pm 0.12^{\mathrm{c}}$ & $59.1 \pm 0.17^{\mathrm{d}}$ \\
45 & $86.8 \pm 0.06^{\mathrm{a}}$ & $85.1 \pm 0.06^{\mathrm{b}}$ & $59.7 \pm 0.12^{\mathrm{c}}$ & $53.3 \pm 0.17^{\mathrm{d}}$ \\
60 & $75.0 \pm 0.12^{\mathrm{a}}$ & $74.8 \pm 0.17^{\mathrm{a}}$ & $54.2 \pm 0.17^{\mathrm{b}}$ & $45.9 \pm 0.17^{\mathrm{c}}$ \\
75 & $66.8 \pm 0.06^{\mathrm{a}}$ & $64.1 \pm 0.17^{\mathrm{a}}$ & $49.1 \pm 0.12^{\mathrm{b}}$ & $40.0 \pm 0.12^{\mathrm{c}}$ \\
90 & $57.1 \pm 0.12^{\mathrm{a}}$ & $55.2 \pm 0.06^{\mathrm{a}}$ & $45.1 \pm 0.06^{\mathrm{b}}$ & $33.1 \pm 0.06^{\mathrm{c}}$ \\
\hline \multicolumn{2}{l}{ Means with different superscripts within the same row are significantly different $(\mathrm{P}<0.05)}$.
\end{tabular}

Means with different superscripts within the same row are significantly different $(\mathrm{P}<0.05)$.

\section{Specific growth rate (SGR):}

The calculation of this parameter (SGR) is useful for comparing growth of prawn of different sizes (Jauncey and Ross, 1982). Changes in SGR value of $M$. rosenbergii-post larvae reared in tanks at different stocking densities were illustrated in Table (8). That SGR of prawn at the end of the experimental period were 3.01 , 2.93, 2.48 and $1.91 \%$ day for stocking densities $200,400,800$ and $1200 \mathrm{prawn} / \mathrm{m}^{2}$, respectively. The tendency in the SGR of prawn observed in the experimental groups, all over the rearing periods, was coincided with the same trend which was observed in the RGR which previously discussed. Since, the SGR values of prawn were initially high and then gradually declined throughout the experimental period. The statistical analysis demonstrated significant specific growth rate differences between densities, while the difference between stocking density 200 and 400 prawn $/ \mathrm{m}^{2}$ was non significant. This is in agreement with the finding of Niu et al. (2003).

A number of possible causes of the reduction of growth in prawn with increasing density have been suggested. These factors may operate singly or simultaneously: Firstly: increasing the density usually exacerbates problems with water quality (Wyban et al., 1988). Secondly: increasing density increases the susceptibility of prawn to disease (Doubrovsky et al., 1988), since, the prawn grows through a series of moltings and during and immediately after molting the prawn is extremely susceptible to physical injury. Thirdly: competition for food may affect the growth at higher densities, as Segal and Roe (1975) who reported deprivation of food to smaller prawn by larger ones when cultured in groups, even if food was given in excess. In addition, in ponds, increasing the density raises pressure on natural food resources (Hopkins et al., 1988) and, as food conversion efficiency is often reduced (Sandifer et al., 1987), the total food costs rise (New, 1987). 
Table 8. Effect of different stocking densities in the first experiment on mean specific growth rate (SGR, \% /day) of Macrobrachium rosenbergii, post-larvae $($ Mean \pm SE)

\begin{tabular}{ccccc}
\hline \multirow{2}{*}{ Period (day) } & \multicolumn{4}{c}{ Stocking rate (Prawn / $\left.\mathbf{~}^{\mathbf{2}}\right)$} \\
\cline { 2 - 5 } & $\mathbf{2 0 0}$ & $\mathbf{4 0 0}$ & $\mathbf{8 0 0}$ & $\mathbf{1 2 0 0}$ \\
\hline 15 & $4.54 \pm 0.012^{\mathrm{a}}$ & $4.54 \pm 0.013^{\mathrm{a}}$ & $3.83 \pm 0.017^{\mathrm{b}}$ & $3.34 \pm 0.014^{\mathrm{c}}$ \\
30 & $4.36 \pm 0.005^{\mathrm{a}}$ & $4.27 \pm 0.012^{\mathrm{a}}$ & $3.44 \pm 0.015^{\mathrm{b}}$ & $3.09 \pm 0.017^{\mathrm{c}}$ \\
45 & $4.16 \pm 0.013^{\mathrm{a}}$ & $4.11 \pm 0.017^{\mathrm{a}}$ & $3.12 \pm 0.005^{\mathrm{b}}$ & $2.85 \pm 0.006^{\mathrm{c}}$ \\
60 & $3.73 \pm 0.017^{\mathrm{a}}$ & $3.72 \pm 0.006^{\mathrm{a}}$ & $2.88 \pm 0.013^{\mathrm{b}}$ & $2.52 \pm 0.012^{\mathrm{c}}$ \\
75 & $3.41 \pm 0.004^{\mathrm{a}}$ & $3.30 \pm 0.012^{\mathrm{a}}$ & $2.67 \pm 0.012^{\mathrm{b}}$ & $2.24 \pm 0.013^{\mathrm{c}}$ \\
90 & $3.01 \pm 0.006^{\mathrm{a}}$ & $2.93 \pm 0.005^{\mathrm{a}}$ & $2.48 \pm 0.006^{\mathrm{b}}$ & $1.91 \pm 0.017^{\mathrm{c}}$ \\
\hline \multicolumn{4}{l}{ Means with different superscripts within the same row are significantly different $(\mathrm{P}<0.05)}$.
\end{tabular}

Means with different superscripts within the same row are significantly different $(\mathrm{P}<0.05)$.

Survival rate (\%):

Table (9) represents the changes of the survival rate of $M$. rosenbergii reared in tanks under different stocking densities. It can be seen that final figures of survival rates at the end of the experimental period showed a great differences among all densities, since it ranged between $48.4 \pm 0.17$ and $81.0 \pm 0.12 \%$ for all densities. The survival rate of prawn was decreased as the stocking densities increased. Similar results were obtained by Tidwell et al. (2004). They showed that the highest rate of survival was recorded at the lowest density. However, in this study, the highest rate of survival was recorded at the lowest density of $200 \mathrm{prawn} / \mathrm{m}^{2}$ and the lowest at 1200 prawn $/ \mathrm{m}^{2}$. The statistical analysis showed that, there were significant differences in the survival rate among densities $\left(200,400,800\right.$ and 1200 prawn $\left./ \mathrm{m}^{2}\right)$. The fourth density $\left(1200 \mathrm{prawn} / \mathrm{m}^{2}\right.$ ) characterized by high number of mortalities (low survival $\%$ of prawn was about $48.4 \%$ ). This poor survival $\%$ could be attributed to poor conditions of the prawn, especially high stocking density. Increased prevalence of disease has been associated with increased stocking density (Doubrovsky et al. 1988), since the prawn grows through a series of molting during or/and after molting, the shrimp is extremely susceptible to physical injury. On the other hand, Segal and Roe (1975) reported that the competition for food on higher densities leads to deprivation of food to smaller prawn by larger ones even if it was given in excess.

Table 9. Effect of different stocking densities in the first experiment on the survival rate (\%) of Macrobrachium rosenbergii, post-larvae (Mean $\pm \mathrm{SE}$ )

\begin{tabular}{ccccc}
\hline \multirow{2}{*}{ Period (day) } & \multicolumn{4}{c}{ Stocking rate (Prawn / $\left.\mathbf{~ m}^{\mathbf{2}}\right)$} \\
\cline { 2 - 5 } & $\mathbf{2 0 0}$ & $\mathbf{4 0 0}$ & $\mathbf{8 0 0}$ & $\mathbf{1 2 0 0}$ \\
\hline 15 & $93.1 \pm 0.15^{\mathrm{a}}$ & $88.2 \pm 0.12^{\mathrm{b}}$ & $77.4 \pm 0.12^{\mathrm{c}}$ & $63.7 \pm 0.06^{\mathrm{d}}$ \\
30 & $90.2 \pm 0.04^{\mathrm{a}}$ & $82.6 \pm 0.17^{\mathrm{b}}$ & $72.3 \pm 0.06^{\mathrm{c}}$ & $59.5 \pm 0.13^{\mathrm{d}}$ \\
45 & $87.5 \pm 0.17^{\mathrm{a}}$ & $79.2 \pm 0.05^{\mathrm{b}}$ & $69.4 \pm 0.17^{\mathrm{c}}$ & $57.6 \pm 0.12^{\mathrm{d}}$ \\
60 & $86.1 \pm 0.12^{\mathrm{a}}$ & $77.8 \pm 0.14^{\mathrm{b}}$ & $67.4 \pm 0.05^{\mathrm{c}}$ & $54.2 \pm 0.06^{\mathrm{d}}$ \\
75 & $84.7 \pm 0.06^{\mathrm{a}}$ & $76.4 \pm 0.12^{\mathrm{b}}$ & $65.3 \pm 0.12^{\mathrm{c}}$ & $52.8 \pm 0.12^{\mathrm{d}}$ \\
90 & $81.0 \pm 0.12^{\mathrm{a}}$ & $72.9 \pm 0.06^{\mathrm{b}}$ & $61.5 \pm 0.17^{\mathrm{c}}$ & $48.4 \pm 0.17^{\mathrm{d}}$ \\
\hline \multicolumn{2}{l}{ Means with different superscripts within the same row are significantly different $(\mathrm{P}<0.05)}$.
\end{tabular}

This study demonstrated that $M$. rosenbergii-post-larvae is capable of good growth with high survival when stocked at $200 \mathrm{prawn} / \mathrm{m}^{2}$ (Table 9). Marques et al. (2000) found that, differences in survival among densities (100, 200, 300, 400, 600 and 800 prawn $/ \mathrm{m}^{2}$ ) were not significant. Differences in prawn growth were significantly higher at 100 and $200 \mathrm{PLs} / \mathrm{m}^{2}$ densities than the highest one (800PLs 
$/ \mathrm{m}^{2}$ ). They concluded that total biomass was increased significantly higher at densities of 400, 600 and $800 \mathrm{PLs} / \mathrm{m}^{2}$, when compared to lower ones (100 and 200 PLs $/ \mathrm{m}^{2}$ ). On the other hand, Wyban et al. (1988) found that increased stocking densities up to $100 \mathrm{P}$. vannamei $/ \mathrm{m}^{2}$ did not appear to affect shrimp growth or survival in experimental ponds in South Carolina. They concluded that shrimp production is doubled by increasing stocking density from $45 / \mathrm{m}^{2}$ to $100 / \mathrm{m}^{2}$.

\section{Feed conversion ratio (FCR):}

Table (10) shows feed conversion ratio (FCR) of $M$. rosenbergii-postlarvae reared in tanks under different stocking densities. The food conversion ratios of prawn at the end of the experimental period were $2.85,2.97,3.58$ and 4.24 for densities 200,400 , 800 and 1200 prawn $/ \mathrm{m}^{2}$, respectively. The mean food conversion ratio of the prawn increased as densities increased, since the FCR achieved in the fourth density was significantly higher than achieved in the first one (being 4.24 and 2.85, respectively). These results are in agreement with those obtained by El-Sherif (2001). He found that mean feed conversion ratio increased as density increased. Also, Siddiqui and AlHinty (1993) found that mean feed conversion ratio (with increasing densities of 2, 4, 8 and 16 prawn $/ \mathrm{m}^{2}$ ) were $2.7,2.9,4.0$ and 4.4 , respectively. While, Willis and Berrigan (1979) reported food conversion ratios of 1.03, 1.31 and 1.45: 1 for densities 5,10 and $20 / \mathrm{m}^{2}$, respectively. It may be assumed that these different values given by different authors are due to the quality of feed used and to other environmental factors.

Table 10. Effect of different stocking densities in the first experiment on the mean feed conversion ratio of $M$. rosenbergii, post-larvae (Mean $\pm \mathrm{SE}$ )

\begin{tabular}{ccccc}
\hline Period (day) & \multicolumn{4}{c}{ Stocking rate (Prawn / $\left.\mathbf{~ m}^{2}\right)$} \\
\cline { 2 - 5 } & $\mathbf{2 0 0}$ & $\mathbf{4 0 0}$ & $\mathbf{8 0 0}$ & $\mathbf{1 2 0 0}$ \\
\hline 15 & $2.28 \pm 0.046^{\mathrm{d}}$ & $2.34 \pm 0.023^{\mathrm{c}}$ & $3.19 \pm 0.052^{\mathrm{b}}$ & $3.55 \pm 0.028^{\mathrm{a}}$ \\
30 & $2.30 \pm 0.006^{\mathrm{d}}$ & $2.38 \pm 0.046^{\mathrm{c}}$ & $3.26 \pm 0.035^{\mathrm{b}}$ & $3.82 \pm 0.012^{\mathrm{a}}$ \\
45 & $2.26 \pm 0.034^{\mathrm{d}}$ & $2.33 \pm 0.017^{\mathrm{c}}$ & $3.17 \pm 0.040^{\mathrm{b}}$ & $3.53 \pm 0.017^{\mathrm{a}}$ \\
60 & $2.29 \pm 0.052^{\mathrm{d}}$ & $2.37 \pm 0.040^{\mathrm{c}}$ & $3.25 \pm 0.029^{\mathrm{b}}$ & $3.81 \pm 0.005^{\mathrm{a}}$ \\
75 & $2.36 \pm 0.035^{\mathrm{d}}$ & $2.45 \pm 0.028^{\mathrm{c}}$ & $3.34 \pm 0.023^{\mathrm{b}}$ & $4.10 \pm 0.011^{\mathrm{a}}$ \\
90 & $2.85 \pm 0.029^{\mathrm{d}}$ & $2.97 \pm 0.012^{\mathrm{c}}$ & $3.58 \pm 0.046^{\mathrm{b}}$ & $4.24 \pm 0.023^{\mathrm{a}}$ \\
\hline \multicolumn{3}{l}{ Means with different superscripts within the same row are significantly different $(\mathrm{P}<0.05)}$.
\end{tabular}

Experiment 2:

Mean individual weights:

It was observed from Table (11) that the initial average weight of juvenile at the beginning of the experiment was $0.30 \pm 0.02 \mathrm{~g}$ for all densities. The finial average body weights at the end of the experimental period showed great differences between different stocking densities, since it was decreased at high stocking density. The stocking density 50 prawn $/ \mathrm{m}^{2}$ showed the highest body weight $(3.47 \mathrm{~g} /$ juvenile) followed by the stocking of 100 prawn $/ \mathrm{m}^{2}$ (3.23g /juvenile), then stocking density of 150 prawn $/ \mathrm{m}^{2}(2.64 \mathrm{~g} /$ juvenile $)$, finaly stocking density of $200 \mathrm{prawn} / \mathrm{m}^{2}(1.48 \mathrm{~g}$ /juvenile). From these results, it could be noticed that the average individual weight of prawn observed in the experimental groups was found to be inversely related to stocking density. This is in agreement with the findings of Tidwell et al. (2004). They reported that lower stocking density gave relatively the highest growth. On the other hand, Wyban et al. (1987) found that individual body weights for marine shrimp 
Penaeus vannamei were 18.1, 17.1, 12.4 and 8.7g for stocking densities 5, 10, 15 and 20 shrimp $/ \mathrm{m}^{2}$, respectively. The statistical analysis indicated that the differences among the mean weight of the prawn obtained from the stocking density of 50, 100, 150 and 200 prawn $/ \mathrm{m}^{2}$ were significant $(\mathrm{P} \leq 0.05)$. But the difference was not significant between stocking rates of 50 and 100 prawn $/ \mathrm{m}^{2}$.

Table 11. Effect of different stocking densities in the second experiment on mean individual weight $(\mathrm{g})$ of $M$. rosenbergii, juvenile (Mean $\pm \mathrm{SE}$ )

\begin{tabular}{cllll}
\hline \multirow{2}{*}{ Period (day) } & \multicolumn{4}{c}{ Stocking rate (Prawn / m } \\
\cline { 2 - 5 } & \multicolumn{1}{c}{$\mathbf{5 0}$} & \multicolumn{1}{c}{$\mathbf{1 0 0}$} & \multicolumn{1}{c}{$\mathbf{1 5 0}$} & $\mathbf{2 0 0}$ \\
\hline At-stocking & $0.30 \pm 0.02$ & $0.30 \pm 0.02$ & $0.30 \pm 0.02$ & $0.30 \pm 0.02$ \\
15 & $0.56 \pm 0.012^{\mathrm{a}}$ & $0.55 \pm 0.017^{\mathrm{a}}$ & $0.50 \pm 0.014^{\mathrm{b}}$ & $0.42 \pm 0.013^{\mathrm{c}}$ \\
30 & $0.97 \pm 0.011^{\mathrm{a}}$ & $0.92 \pm 0.012^{\mathrm{a}}$ & $0.79 \pm 0.023^{\mathrm{b}}$ & $0.57 \pm 0.025^{\mathrm{c}}$ \\
45 & $1.52 \pm 0.023^{\mathrm{a}}$ & $1.42 \pm 0.021^{\mathrm{a}}$ & $1.17 \pm 0.017^{\mathrm{b}}$ & $0.74 \pm 0.012^{\mathrm{c}}$ \\
60 & $2.10 \pm 0.013^{\mathrm{a}}$ & $1.96 \pm 0.170^{\mathrm{b}}$ & $1.61 \pm 0.022^{\mathrm{c}}$ & $0.96 \pm 0.017^{\mathrm{d}}$ \\
75 & $2.78 \pm 0.025^{\mathrm{a}}$ & $2.59 \pm 0.020^{\mathrm{a}}$ & $2.12 \pm 0.011^{\mathrm{b}}$ & $1.21 \pm 0.006^{\mathrm{c}}$ \\
90 & $3.47 \pm 0.014^{\mathrm{a}}$ & $3.23 \pm 0.012^{\mathrm{a}}$ & $2.64 \pm 0.018^{\mathrm{b}}$ & $1.48 \pm 0.023^{\mathrm{c}}$ \\
\hline
\end{tabular}

Means with different superscripts within the same row are significantly different $(\mathrm{P}<0.05)$.

\section{Mean weight gain:}

Table (12) illustrates the mean weight gain at 15 days intervals for all the stocking densities. The average weight gains were $0.69,0.64,0.52$ and $0.27 \mathrm{~g} / \mathrm{prawn}$ at the end of the experimental period for the stocking densities 50,100, 150 and $200 \mathrm{prawn} / \mathrm{m}^{2}$, respectively. The data also indicated that the mean weight gain sharply decreased with increasing stocking densities. Such results have been confirmed by El-Sherif (2001). The statistical analysis indicated that there were significant $(\mathrm{P} \leq 0.05)$ differences among the stocking densities, but not between 50 and $100 \mathrm{prawn} / \mathrm{m}^{2}$.

Table 12. Effect of different stocking densities in the second experiment on mean weight gain (g/individual prawn /15 days) of $M$. rosenbergii, juvenile (Mean $\pm \mathrm{SE}$ )

\begin{tabular}{ccccc}
\hline \multirow{2}{*}{ Period(day) } & 50 & \multicolumn{4}{c}{ Stocking rate $\left(\right.$ Prawn $\left./ \mathrm{m}^{2}\right)$} \\
\cline { 2 - 5 } & $0.26 \pm 0.012^{\mathrm{a}}$ & $0.25 \pm 0.011^{\mathrm{a}}$ & $0.18 \pm 0.006^{\mathrm{b}}$ & $0.12 \pm 0.014^{\mathrm{c}}$ \\
30 & $0.41 \pm 0.017^{\mathrm{a}}$ & $0.37 \pm 0.022^{\mathrm{a}}$ & $0.29 \pm 0.015^{\mathrm{b}}$ & $0.15 \pm 0.006^{\mathrm{c}}$ \\
45 & $0.55 \pm 0.023^{\mathrm{a}}$ & $0.50 \pm 0.005^{\mathrm{a}}$ & $0.38 \pm 0.020^{\mathrm{b}}$ & $0.18 \pm 0.017^{\mathrm{c}}$ \\
60 & $0.58 \pm 0.012^{\mathrm{a}}$ & $0.54 \pm 0.014^{\mathrm{a}}$ & $0.44 \pm 0.011^{\mathrm{b}}$ & $0.22 \pm 0.015^{\mathrm{c}}$ \\
75 & $0.68 \pm 0.015^{\mathrm{a}}$ & $0.63 \pm 0.021^{\mathrm{a}}$ & $0.51 \pm 0.005^{\mathrm{b}}$ & $0.25 \pm 0.052^{\mathrm{c}}$ \\
90 & $0.69 \pm 0.011^{\mathrm{a}}$ & $0.64 \pm 0.013^{\mathrm{a}}$ & $0.52 \pm 0.023^{\mathrm{b}}$ & $0.27 \pm 0.015^{\mathrm{c}}$ \\
\hline Means with different superscripts within the same row are significantly different $(\mathrm{P}<0.05)$.
\end{tabular}

Average daily weight gain:

Table (13) represents the changes of the average daily weight gain of $M$. rosenbergii-juveniles reared at different stocking densities. It can be seen from that the averages of weight gains /prawn /day were $0.017,0.016,0.012$ and $0.008 \mathrm{~g}$ for stocking densities 50,100, 150 and 200 prawn $/ \mathrm{m}^{2}$, respectively during the first period (15 days). At the end of the experimental period, the data indicated that, the average daily weight gain of prawn reached its maximum of $0.046,0.043,0.035$ and $0.018 \mathrm{~g}$, respectively. It can be seen that there were differences in the average daily weight gain of prawn at different stocking densities. The gain per prawn per day decreased as the stocking density increased. Similar results were obtained by Zaki 
and Abdel-Halim (1997). The statistical analysis showed that there were significant differences among the average daily weight gain of the prawn at different stocking density. But the difference was not significant between stocking density of 50 and 100 prawn $/ \mathrm{m}^{2}$.

Table 13. Effect of different stocking densities in the second experiment on the average daily weight gain (g/day) of $M$. rosenbergii, juvenile (Mean $\pm \mathrm{SE}$ )

\begin{tabular}{ccccc}
\hline \multirow{2}{*}{ Period (day) } & \multicolumn{4}{c}{ Stocking rate $\left(\right.$ Prawn $\left./ \mathrm{m}^{2}\right)$} \\
\cline { 2 - 5 } & 50 & 100 & 150 & 200 \\
\hline 15 & $0.017 \pm 0.001^{\mathrm{a}}$ & $0.016 \pm 0.003^{\mathrm{a}}$ & $0.012 \pm 0.006^{\mathrm{b}}$ & $0.008 \pm 0.005^{\mathrm{c}}$ \\
30 & $0.027 \pm 0.005^{\mathrm{a}}$ & $0.024 \pm 0.001^{\mathrm{a}}$ & $0.019 \pm 0.003^{\mathrm{b}}$ & $0.010 \pm 0.002^{\mathrm{c}}$ \\
45 & $0.036 \pm 0.002^{\mathrm{a}}$ & $0.033 \pm 0.013^{\mathrm{a}}$ & $0.025 \pm 0.012^{\mathrm{b}}$ & $0.012 \pm 0.013^{\mathrm{c}}$ \\
60 & $0.039 \pm 0.011^{\mathrm{a}}$ & $0.036 \pm 0.005^{\mathrm{a}}$ & $0.029 \pm 0.011^{\mathrm{b}}$ & $0.015 \pm 0.006^{\mathrm{c}}$ \\
75 & $0.045 \pm 0.013^{\mathrm{a}}$ & $0.042 \pm 0.012^{\mathrm{a}}$ & $0.034 \pm 0.002^{\mathrm{b}}$ & $0.017 \pm 0.013^{\mathrm{c}}$ \\
90 & $0.046 \pm 0.006^{\mathrm{a}}$ & $0.043 \pm 0.011^{\mathrm{a}}$ & $0.035 \pm 0.004^{\mathrm{b}}$ & $0.018 \pm 0.012^{\mathrm{c}}$ \\
\hline \multicolumn{2}{l}{ Means with different superscripts within the same row are significantly different $(\mathrm{P}<0.05)}$.
\end{tabular}

Relative growth rate ( $R G R)$ :

Results concerning the RGR are illustrated in Table (14). It can be seen that the percentages in weight gain of prawn or the stocking densities 50, 100, 150 and 200 prawn $/ \mathrm{m}^{2}$ were $86.66,83.33,60.00$ and $40.00 \%$, respectively during the first rearing period. Thereafter, the weight gain percentage of prawn being gradually decreased by time. Similar results were obtained by Al-Farsi (1997) who indicated that the RGR of shrimp ( $P$. japonicus-juvenile) was initially high and then gradually declined. From data obtained, it could be noticed that the RGR of $M$. rosenbergii-juvenile varied by varying the stocking density, since the RGR decreases as the stocking density increased $\left(50,100,150\right.$ and 200 prawn $\left./ \mathrm{m}^{2}\right)$. It can be seen from the table that the RGR at the end of the experimental period was decreased (24.82, 24.71, 24.25 and $22.31 \%$ ) by increasing stocking densities from 50, 100, 150 to 200 prawn $/ \mathrm{m}^{2}$, respectively. The statistical analysis showed that the differences among the stocking densities were significant. But the difference between stocking density 50 and 100 prawn $/ \mathrm{m}^{2}$ was not significant. This is in full agreement with that found by Tidwell et al. (2003).

Table 14. Effect of different stocking densities in the second experiment on mean relative growth rate $(\%$ growth) of $M$. rosenbergii, juvenile (Mean $\pm \mathrm{SE}$ )

\begin{tabular}{ccccc}
\hline \multirow{2}{*}{ Period (day) } & \multicolumn{4}{c}{ Stocking rate (Prawn / m } \\
\cline { 2 - 5 } & $\mathbf{5 0}$ & $\mathbf{1 0 0}$ & $\mathbf{1 5 0}$ & $\mathbf{2 0 0}$ \\
\hline 15 & $86.66 \pm 0.12^{\mathrm{a}}$ & $83.33 \pm 0.17^{\mathrm{b}}$ & $60.00 \pm 0.01^{\mathrm{c}}$ & $40.00 \pm 0.03^{\mathrm{d}}$ \\
30 & $73.21 \pm 0.14^{\mathrm{a}}$ & $67.27 \pm 0.05^{\mathrm{b}}$ & $58.00 \pm 0.17^{\mathrm{c}}$ & $37.50 \pm 0.12^{\mathrm{d}}$ \\
45 & $56.70 \pm 0.05^{\mathrm{a}}$ & $54.35 \pm 0.13^{\mathrm{a}}$ & $48.10 \pm 0.14^{\mathrm{b}}$ & $31.57 \pm 0.17^{\mathrm{c}}$ \\
60 & $38.16 \pm 0.17^{\mathrm{a}}$ & $38.03 \pm 0.11^{\mathrm{a}}$ & $37.61 \pm 0.15^{\mathrm{b}}$ & $29.72 \pm 0.05^{\mathrm{c}}$ \\
75 & $32.38 \pm 0.17^{\mathrm{a}}$ & $32.14 \pm 0.02^{\mathrm{a}}$ & $31.67 \pm 0.06^{\mathrm{b}}$ & $26.04 \pm 0.01^{\mathrm{c}}$ \\
90 & $24.82 \pm 0.11^{\mathrm{a}}$ & $24.71 \pm 0.06^{\mathrm{a}}$ & $24.25 \pm 0.04^{\mathrm{b}}$ & $22.31 \pm 0.02^{\mathrm{c}}$ \\
\hline
\end{tabular}

Means with different superscripts within the same row are significantly different $(\mathrm{P}<0.05)$.

Specific growth rate "SGR" :

Table (15) illustrates the changes in the SGR of M. rosenbergii- juveniles under different treatments. The tendency in the SGR of prawn observed in the experimental groups, all over the periods of rearing, was coincided with the same trend which was 
observed in the RGR which previously discussed. Since, the SGR values of prawn in all treatments were initially high and then gradually declined throughout the experimental period of 90 days. In the same time, the SGR of prawn varied by varying the treatments. The results show that the SGR of prawn at the end of the experimental period were decreased $(1.48,1.47,1.46$ and $1.34 \%$ / day) for stocking densities 50, 100, 150 and 200 prawn $/ \mathrm{m}^{2}$, respectively. The statistical analysis showed that the differences among the stocking densities on the specific growth rates of prawn were significant $(\mathrm{P}<0.05)$. But the differences between stocking densities 50 and 100 prawn $/ \mathrm{m}^{2}$ were not significant. Similar results was obtained by Tidwell et al. (2004).

Table 15. Effect of different stocking densities in the second experiment on mean specific growth rate $(\% /$ day) of $M$. rosenbergii, juvenile (Mean $\pm \mathrm{SE}$ )

\begin{tabular}{ccccc}
\hline Period (day) & \multicolumn{4}{c}{ Stocking rate (Prawn / $\left.\mathbf{~}^{\mathbf{2}}\right)$} \\
\cline { 2 - 5 } & $\mathbf{5 0}$ & $\mathbf{1 0 0}$ & $\mathbf{1 5 0}$ & $\mathbf{2 0 0}$ \\
\hline 15 & $4.16 \pm 0.011^{\mathrm{a}}$ & $4.04 \pm 0.006^{\mathrm{b}}$ & $3.13 \pm 0.004^{\mathrm{c}}$ & $2.24 \pm 0.025^{\mathrm{d}}$ \\
30 & $3.66 \pm 0.017^{\mathrm{a}}$ & $3.43 \pm 0.013^{\mathrm{b}}$ & $3.05 \pm 0.021^{\mathrm{c}}$ & $2.04 \pm 0.017^{\mathrm{d}}$ \\
45 & $3.12 \pm 0.005^{\mathrm{a}}$ & $2.89 \pm 0.018^{\mathrm{b}}$ & $2.62 \pm 0.035^{\mathrm{c}}$ & $1.74 \pm 0.012^{\mathrm{d}}$ \\
60 & $2.15 \pm 0.012^{\mathrm{a}}$ & $2.14 \pm 0.015^{\mathrm{a}}$ & $2.12 \pm 0.018^{\mathrm{a}}$ & $1.73 \pm 0.018^{\mathrm{b}}$ \\
75 & $1.87 \pm 0.017^{\mathrm{a}}$ & $1.85 \pm 0.020^{\mathrm{a}}$ & $1.83 \pm 0.012^{\mathrm{a}}$ & $1.54 \pm 0.005^{\mathrm{b}}$ \\
90 & $1.48 \pm 0.005^{\mathrm{a}}$ & $1.47 \pm 0.011^{\mathrm{a}}$ & $1.46 \pm 0.017^{\mathrm{a}}$ & $1.34 \pm 0.013^{\mathrm{b}}$ \\
\hline \multicolumn{4}{l}{}
\end{tabular}

Survival rate (\%) :

Table (16) shows the survival rate of $M$. rosenbergii-juveniles reared in tanks under different stocking densities. The survival rates of prawn during the experimental period were high at all densities. This is mainly due to: Firstly: the acclimation of the prawn prior to the start of stocking in tanks. Secondly: this experiment started with $M$. rosenbergii-juveniles of an initial average weight $0.3 \mathrm{~g}$, such size shows high tolerance to the unfavorable conditions (Zaki and Abdel-Halim, 1997). Thirdly: the ecological conditions throughout the experimental period were suitable for prawn rearing, especially the average water temperatures (which ranged between 27.6 and $26.5^{\circ} \mathrm{C}$ ), since Marques et al., 2000 noted that optimal water temperatures for optimum growth and survival of $M$. rosenbergii are $26-31^{\circ} \mathrm{C}$. The results showed that the survival \% of prawn were decreased $(72.2,69.4,62.9$ and $51.4 \%$ ) for stocking densities 50,100, 150 and 200 prawn $/ \mathrm{m}^{2}$, respectively at the end of the experimental period. These results indicated that the survival $\%$ decreased with increasing of the stocking density. This is in full agreement with the results reported before by Tidwell et al. (2003 \& 2004). On the other hand, Gopal Rao et al. (1986) found that the survival rates of $M$. malcolmsonii in ponds ranged from 44.2 to $57.2 \%$ for the 390 days grow out period. Low survival was due to algal blooms of Spirogyra sp. and Euglena sp., which led to depletion of dissolved oxygen and consequent by ecological imbalance. Wyban et al. (1987) showed that the survival rate of shrimp (Penaeus vannamei) averaged $70.8 \pm 6.3 \%$ and there were no significant differences among densities $\left(5,10,15\right.$ and $\left.20 \mathrm{shrimp} / \mathrm{m}^{2}\right)$. The statistical analysis showed that significant differences in survival \% were observed among the densities, while the difference between stocking density 50 and $100 \mathrm{prawn} / \mathrm{m}^{2}$ was non significant. 
Table 16. Effect of different stocking densities on survival rate (\%) of $M$. rosenbergii, juvenile (Mean $\pm \mathrm{SE}$ )

\begin{tabular}{ccccc}
\hline \multirow{2}{*}{ Period (day) } & \multicolumn{4}{c}{ Stocking rate (Prawn / $\left.\mathbf{~}^{\mathbf{2}}\right)$} \\
\cline { 2 - 5 } & $\mathbf{5 0}$ & $\mathbf{1 0 0}$ & $\mathbf{1 5 0}$ & $\mathbf{2 0 0}$ \\
\hline 15 & $89.0 \pm 0.115^{\mathrm{a}}$ & $86.1 \pm 0.112^{\mathrm{a}}$ & $79.6 \pm 0.123^{\mathrm{b}}$ & $66.6 \pm 0.152^{\mathrm{c}}$ \\
30 & $83.3 \pm 0.120^{\mathrm{a}}$ & $80.6 \pm 0.170^{\mathrm{a}}$ & $74.1 \pm 0.057^{\mathrm{b}}$ & $61.1 \pm 0.116^{\mathrm{c}}$ \\
45 & $82.0 \pm 0.057^{\mathrm{a}}$ & $78.2 \pm 0.120^{\mathrm{a}}$ & $72.2 \pm 0.174^{\mathrm{b}}$ & $59.7 \pm 0.231^{\mathrm{c}}$ \\
60 & $81.2 \pm 0.110^{\mathrm{a}}$ & $77.7 \pm 0.231^{\mathrm{a}}$ & $70.4 \pm 0.115^{\mathrm{b}}$ & $56.9 \pm 0.211^{\mathrm{c}}$ \\
75 & $77.7 \pm 0.173^{\mathrm{a}}$ & $75.0 \pm 0.017^{\mathrm{a}}$ & $66.6 \pm 0.180^{\mathrm{b}}$ & $54.2 \pm 0.059^{\mathrm{c}}$ \\
90 & $72.2 \pm 0.116^{\mathrm{a}}$ & $69.4 \pm 0.123^{\mathrm{a}}$ & $62.9 \pm 0.113^{\mathrm{b}}$ & $51.4 \pm 0.173^{\mathrm{c}}$ \\
\hline \multicolumn{4}{c}{ Means with different superscripts within the same row are significantly different $(\mathrm{P}<0.05)}$.
\end{tabular}

\section{Feed conversion ratio (FCR):}

Data concerning the feed conversion ratio of $M$. rosenbergii-juveniles reared in tanks under different stocking densities were illustrated in Table (17). Feed conversion was increased $(3.19,3.32,4.63$ and 5.80) for stocking densities 50, 100, 150 and 200 prawn $/ \mathrm{m}^{2}$, respectively (i.e. feed conversion ratio of prawn increased as densities increased). Such results coincide with those of Tidwell et al. (2004).

Table 17. Effect of different stocking densities in the second experiment on mean feed conversion ratio of $M$. rosenbergii, juvenile (Mean $\pm \mathrm{SE}$ )

\begin{tabular}{ccccc}
\hline \multirow{2}{*}{ Period (day) } & \multicolumn{4}{c}{ Stocking rate (Prawn / $\left.\mathbf{~}^{\mathbf{2}}\right)$} \\
\cline { 2 - 5 } & $\mathbf{5 0}$ & $\mathbf{1 0 0}$ & $\mathbf{1 5 0}$ & $\mathbf{2 0 0}$ \\
\hline 15 & $2.37 \pm 0.040^{\mathrm{c}}$ & $2.43 \pm 0.017^{\mathrm{c}}$ & $3.49 \pm 0.051^{\mathrm{b}}$ & $4.02 \pm 0.011^{\mathrm{a}}$ \\
30 & $2.39 \pm 0.337^{\mathrm{c}}$ & $2.46 \pm 0.035^{\mathrm{c}}$ & $3.53 \pm 0.017^{\mathrm{b}}$ & $4.12 \pm 0.012^{\mathrm{a}}$ \\
45 & $2.35 \pm 0.028^{\mathrm{c}}$ & $2.42 \pm 0.011^{\mathrm{c}}$ & $3.47 \pm 0.040^{\mathrm{b}}$ & $3.94 \pm 0.023^{\mathrm{a}}$ \\
60 & $3.38 \pm 0.046^{\mathrm{c}}$ & $2.45 \pm 0.029^{\mathrm{c}}$ & $3.51 \pm 0.005^{\mathrm{b}}$ & $4.16 \pm 0.035^{\mathrm{a}}$ \\
75 & $2.46 \pm 0.034^{\mathrm{c}}$ & $2.51 \pm 0.006^{\mathrm{c}}$ & $3.56 \pm 0.028^{\mathrm{b}}$ & $4.35 \pm 0.023^{\mathrm{a}}$ \\
90 & $3.19 \pm 0.052^{\mathrm{d}}$ & $3.32 \pm 0.012^{\mathrm{c}}$ & $4.63 \pm 0.017^{\mathrm{b}}$ & $5.80 \pm 9.006^{\mathrm{a}}$ \\
\hline \multicolumn{4}{l}{ Means with different superscripts within the same row are significantly different $(\mathrm{P}<0.05)}$.
\end{tabular}

Chemical composition of prawn tissue:

Table (18) showed that protein content and ash content increased with increasing stocking densities, while fat content decreased as the stocking densities increased. However, the differences were not significant in crude protein, ether extract and ash among carcasses of all stocking density groups. These results are in agreement with those obtained by Zaki and Abdel-Halim (1997), who found that the dry matter content of prawn bodies was $25.18-26.47 \%$, the crude protein was $53.83-57.54 \%$, ether extract was $5.41-5.81 \%$ and ash content was $18.69-20.56 \%$ for the juvenile $M$. rosenbergii (on dry matter basis). Also, El-Sherif (2001) revealed that dry matter contents had ranged between 23.81 and $24.33 \%$ and differences due to stocking density (25 and 50L/L) were insignificant for the juvenile $M$. rosenbergii. On the other hand, Alava and Pascual (1987) and Sarac et al. (1994) found that the crude protein content of dry prawn bodies was $61.8-75.8 \%$ for the juvenile Penaeus monodon and $62.1-67.8 \%$ for the juvenile Metapenaeus monoceros, respectively. The differences in body composition could be attributed to several factors such as variations in species, age, molting cycle and available nutrients in diets. 
Table 18. Chemical composition (on dry matter basis\%) of whole body of $M$. rosenbergii-juvenile in the second experiment reared at different densities for 90 days

\begin{tabular}{cccccc}
\hline $\begin{array}{c}\text { Stocking rate } \\
(\text { Prawn/m }\end{array}$ & DM & CP & EE & Ash & Rest \\
\hline 50 & $26.2 \pm 0.1^{\mathrm{a}}$ & $55.3 \pm 0.01^{\mathrm{a}}$ & $5.6 \pm 0.0^{\mathrm{a}}$ & $20.5 \pm 0.01^{\mathrm{a}}$ & $18.6 \pm 0.2^{\mathrm{a}}$ \\
100 & $25.9 \pm 0.0^{\mathrm{a}}$ & $55.6 \pm 0.2^{\mathrm{a}}$ & $5.3 \pm 0.1^{\mathrm{a}}$ & $20.9 \pm 0.05^{\mathrm{a}}$ & $18.2 \pm 0.0^{\mathrm{a}}$ \\
150 & $25.5 \pm 0.01^{\mathrm{ab}}$ & $55.9 \pm 0.04^{\mathrm{a}}$ & $5.2 \pm 0.4^{\mathrm{a}}$ & $21.3 \pm 0.1^{\mathrm{a}}$ & $17.6 \pm 0.2^{\mathrm{b}}$ \\
200 & $25.2 \pm 0.02^{\mathrm{b}}$ & $56.2 \pm 0.5^{\mathrm{a}}$ & $4.8 \pm 0.01^{\mathrm{a}}$ & $21.5 \pm 0.0^{\mathrm{a}}$ & $17.5 \pm 0.1^{\mathrm{b}}$ \\
\hline
\end{tabular}

Means with different superscripts within the same column are significantly different at $(\mathrm{P} \leq 0.05)$.

$\mathrm{DM}=$ Dry Matter (\%), CP= Crude Protein (\%), EE= Ether Extract (\%).

\section{CONCLUSION}

It could be concluded from the previous results that stoking density of fresh water brawn (M.rosenbergii) juveniles (average weight $0.3 \mathrm{~g}$ ) were more suitable for monoculture than postlarvae (average weight 0.04). Increasing stoking density of either postlarvae or juveniles resulted lower growth performance, survival rate and feed utilization.

\section{REFERENCES}

Alava, V.R. and E.P. Pascual, 1987. Carbohydrate requirments of Penaeus monodon (Fabricius) juveniles. Aquaculture, 61: 211-217.

Al-Farsi, E.M., 1997. Studies on the production of marine shrimp. M.Sc. Thesis, Faculty of Agri. Suez Canal University, Egypt.

A.O.A.C., 1990. Official Methods of Analysis. Association of Official Analytical Chemists, Washington, D.C., U.S.A.

Brown, J.H., J. Wickins and M.H. Maclean, 1991. The effect of water hardness on growth and carapace mineralization of juvenile freshwater prawn M. rosenbergii (de Man). Aquaculture, 95: 329 - 345.

Chen, L.C., 1990. Aquaculture in Taiwan. Fishing News Books. Blakwell Scientific Publications, Oxford.

D'Abramo, L.R., J.M. Heinen, , H.R Robinette and J.S Collins, 1989. Production of the freshwater prawn (M. rosenbergii) stocked as juveniles at different densities in temperate zone ponds. J. World Aquaculture Soc., 20: 81 - 89.

De-Silva, S.S. and T.V. Anderson, 1995. Fish Nutrition in Aquaculture (Book). Printed in Great Britain by st. Edmundsbuzy Press, Bury St. Edmunds, Subfolk.

Doubrovsky, A., J.L. Paynter, S.K. Sambhi, J.G. Atherton and R.J.G. Lester, 1988. Observation on the ultrastructure of boculovirus in Australian Penaeus monodon and Penaeus mereguiensis. Aust. J. Mar. Freshwater Res., 39: 743 - 749.

El-Gayar, O.F., S.S. Sadek and P. Leung, 1994. Aquaculture in Egypt: A review. Aquacult. Conf. July, 1994, Taiwan.

El-Sherif, M.S., 2001. Studies on growth performance of prawn (Macrobrachium rosenbergii) as affected by type of feeding and stocking density. J. Agric Sci. Mansoura Univ., 26: 4141 - 4149.

Gopal Rao, K., O. Ramachandra Reddy, P.V.A.N. Rama Rao and R. Ramakrishna, 1986. Monoculture of Indian freshwater prawn M. rosenbergii (Milne Edwards). Aquaculture, 53: $67-73$. 
Harrell, R.M., J.H. Kerby and R.V. Minton, 1990. Culture and propagation of striped bass and its hybrids Striped Bass Committee, Southern Division, American Fisheries, Society, Bethesda, Maryland.

Hopkins, J.S., M.L. Baird, O.G. Grados, P.P. Maier, P.A. Sandifer and A.D. Stokes, 1988. Impacts of intensive shrimp production on the culture pond ecocystem. J. World Aquaculture Soc. (Aquacult. Communiques), $19: 37 \mathrm{~A}$.

Jauncey, K. and B. Ross, 1982. A Guid to Tilapia Feeds and Feeding. (B00k) the Univ. of Stirling, Scotland.

Lee, D.O'C. and J.F. Wickins, 1992. Crustacean farming (Book) the Univ. Press, Cambridge, Great Britain

Ling, S.W., 1977. Aquaculture in Southeast Asia: Historical over view. University of Washington Press. Seattle, WA. 108pp.

Marques, H.L.A., J.V. Lombardi and M.V. Boock, 2000. Stocking densities for nursery phase culture of the freshwater prawn (Macrobrachium rosenbergii) in cages. Aquaculture, 187: $127-132$.

Mei Chen, S. and J. Chu Chen, 2003. Effects of pH on survival, growth, molting and feeding of giant freshwater prawn M. rosenbergii. Aquaculture, 218: $613-623$.

NRC, National Research Council, 1983. Nutrient requirements of warm water fishes and shellfishes. National Academy Press. Washington, D.C.

New, M.B., 1987. Feed and feeding of fish and shrimp. A manual on the preparation and presentation of compound feeds for shrimp and fish in aquaculture. Report ADCP/REP/87/26. United Nations Development Program. Food and Agriculture Organization of the United Nation, Rome, 275pp.

New, M.B., 2000a. History and global status of freshwater prawn farming. In: New, M.B. and Valenti, W.C. (Eds), Freshwater Prawn Culture: The Farming of $M$. rosenbergii, Blackwell, Malden, MA, USA, PP. $1-11$.

New, M.B., 2000b. Commercial freshwater prawn farming around the world. In: New, M.B. and Valenti, W.C. (Eds), Freshwater Prawn Culture: The Farming of M. rosenbergii, Blackwell, Malden, MA, USA, PP. 290 - 325.

New, M.B. and S. Singholka, 1985. Freshwater Prawn Farming. A Manual for the culture of M. rosenbergii. FAO Fish. Tech. Pap., (225) Rev. 1, 118pp.

Niu, C.J., D. Lee, S. Goshima and S. Nakao, 2003. Effects of temperature on food consumption, growth and oxygen consumption of freshwater prawn, $M$. rosenbergii (de Man, 1879) post larvae. Aquaculture Research, 34: 501 - 506.

Ra'anan, Z., 1982. The ontogeny of social structure in the freshwater prawn $M$. rosenbergii (de Man). Ph. D. Thesis. The Hebrew University of Jerusalem, Israel, $101 \mathrm{p}$.

Sadek, S.S. and F. El-Gayar, 1993. Production of the giant freshwater prawn ( $M$. rosenbergii) in brackish water ponds (Egypt). First International Symposium on Aquaculture Technology and Investment Opportunities. Riyadh, 11 - 14 April, 1993.

Sadek, S.S. and J. Moreau, 1996. Prawn (M. rosenbergii) culture in earthen ponds in the Nile Delta, Egypt: culture parameters and cost-benefits. The Israeli Journal of Aquaculture-Bamidgeh, 48: $201-218$.

Sandifer, P.A., J.S. Hopkins and A.D. Stokes, 1987. Intensive culture potential of Penaeus vannami. J. World Maricult. Soc., 18: 94 - 100.

Sarac, H.Z., N.P. McMeniman, H. Thaggard, M. Gravel, S. Tabrett and J. Saunders, 1994. Relationships between the weight and chemical composition of exuvia and 
whole body of the black tiger prawn, Penaeus monodon. Aquaculture, 119: 249 258.

SAS, 1988. SAS user's guide. Statistics. A. A. Ray. ed. SAS Inst., Inc, Cary, NC., 67 (3).

Segal, E. and A. Roe, 1975. Growth and behavior of post-juvenile Macrobrachium rosenbergii (de man) in close confinement. Proc. World Maricult. Soc., 6: 67 88.

Siddiqui, A.Q. and H.M. Al-Hinty, 1993. Feasibility of freshwater prawn $M$. rosenbergii culture in the centeral region of Saudi Arabia. Effects of density on growth, yield and population structure. First international symposium on Aquaculture technology and investment opportunities. Riyadh, 11-14 April, 304 $-329 \mathrm{pp}$.

Tidwell, J.H. and L. D'Abramo, 2000. Growout systems: culture in temperature zones. In: New, M.B. and Valenti, W.C. (Eds), Freshwater Prawn Culture: The farming of $M$. rosenbergii. Blackwell, Malden, MA, USA, PP. 177 - 186.

Tidwell, J.H., S.D. Coyle, L.A. Bright, A. VanArnum and C. Weibel, 2003. The effects of size grading and length of nursery period on growth and population structure of freshwater prawns stocked in temperate zone ponds with added substrates. Aquaculture, 218: 209 - 218.

Tidwell, J.H., S.D. Coyle and S. Dasgupta, 2004. Effects of stocking different fractions of size graded juvenile prawns on production and population structure during a temperature-limited growout period. Aquaculture, 231: $123-134$.

Tidwell, J.H., L.R. D'Abramo, S.D. Coyle and D. Yasharian, 2005. Overview of recent research and development in temperate culture of the freshwater prawn $(M$. rosenbergii De Man) in the South Central United States. Aquaculture Research, 36: $264-277$.

Wang, Y.C., C.F. Lo, P.S. Chang and G.H. Kou, 1998. Experimental infection of white spot baculovirus in some cultured and wild decapods in Taiwan. Aquaculture, 164: $221-231$.

Willis, S.A. and M.E. Berrigan, 1979. Effects of stocking size and density on growth and survival of $M$. rosenbergii (DE MAN) in ponds. Proc. World Maricul. Soc., 10: $251-264$.

Wyban, J.A., C.S. Lee, V.T. Sato, J.N. Sweeney and W.K.Jr. Richards, 1987. Effect of stocking density on shrimp growth rates in manure-fertilized ponds. Aquaculture, 61: $23-32$.

Wyban, J.A., J.N. Sweeney and R.A. Kanina, 1988. Shrimp yields and economic potential of intensive round pond system. J. World Maricult. Soc., 19: 210 - 217.

Zaki, M.A. and A.M.M. Abdel-Halim, 1997. Growth of freshwater prawn M. rosenbergii under different organic fertilization regimes and stocking densities. Egypt. J. Agric. Res., 75: 283 -292.

Zar, J.H., 1996. Biostatistical Analysis. Prentice Hall, Upper Saddle River, NJ, USA. 


\section{تأثير كثافة التخزين والوزن المبائى على أداء النمو للطور اليافع وطور ما بعد اليرقة لجمبرى المياه العذبة}

محمد سعد الشريف، حافظ محمد خريبة، مرفت على محمد قسم الإنتاج الحيواتسى والثروة السمكية، كلية الزراعة، جامعة قناة السويس، الإسعاعيلية، مصر

استهدفت هذه الدراسة تربية طور ما بعد اليرقة لجمبرى المياه العذبة (تجربة () بمنوسط وزن (ع ...

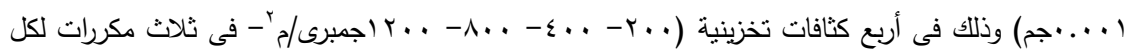

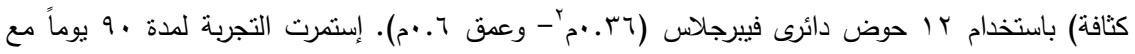

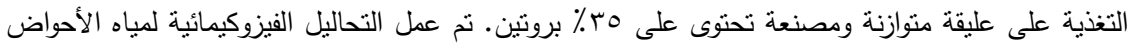

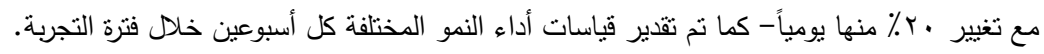

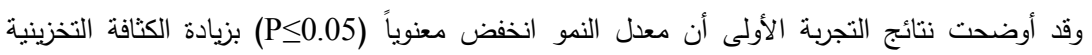
للجمبرى- كما أن معدل البقاء أظهر علاقة عكسية مع الكثافات التخزينية المختلفة حيث كانت الفروف بمعنوية عالية. وقد زاد معامل تحويل الغذاء (FCR) بزيادة كثافة التخزين وكانت الفروق معنوية بين الكثافات الأربع.

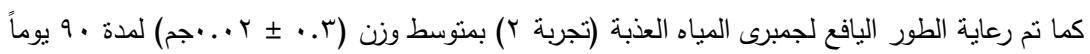

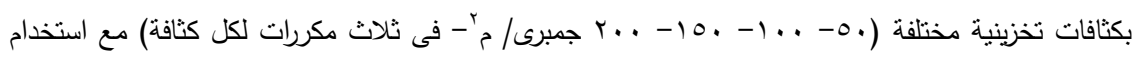

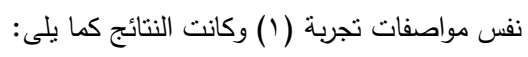

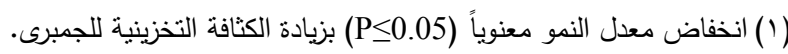
(Y) معدل البقاء للجمبرى كان على علاقة عكسية مع الكثافات التخزينية المستخدمة. (ץ) زبادة معامل تحويل الغذاء (FCR) بزيادة كثافة التخزين.

(ع) بزيادة الكثافة التخزينية زاد كل من المحتوى البروتينى ورماد الجسم بينما قل كل من الدهن والمادة الجافة

$$
\text { لجسم الجمبرى- وكانت الفروق غير معنوية فى كل الأحوال. }
$$

وعلى ذلك يمكن النوصية بتطبيق الإستزراع المنفرد لكل من الطور اليافع لجمبرى المياه العذبة (بمنوسط

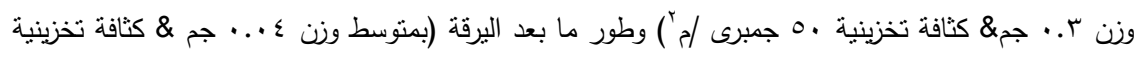

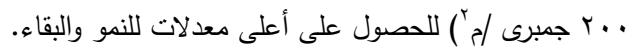

